\title{
Effect of Defatted Moringa Seed Flour on the Proximate, Mineral and Sensory Properties of Bread
}

\author{
B.M. Yelmi Samuel E. Eduzor E. Lamido A.U. \\ Department Of Food Science And Technology \\ Federal Polytechnic Bauchi, Nigeria West Africa
}

\begin{abstract}
The study investigated the effect of Moringa seed flour on the proximate, mineral and sensory properties of bread. The flour samples used for the bread production were supplemented with defatted Moringa seed flour as follows: Wheat flour: defatted Moringa seed flour A(100:0), B (95:5) C (90:10) D (85:15) and E (80:20). The result of the proximate composition of bread ranged as follows: protein (15.66 to $17.16 \%$ ), crude fibre (2.5 to $5.37 \%$ ), ash $(0.23$ to $1.81 \%)$, moisture content (23.96 to $12.48 \%)$, crude fat $(7.12$ to $0.29 \%)$. There was no significant (PL 0.05) difference in the sensory attributes of among the samples in terms of colour. However, significant (PL 0.05) difference was observed in terms of flavour, texture and taste. Incorporating Moringa seeds in baked foods may be exploited as a means of boosting nutrition in Africa and Asia where malnutrition is prevalent.
\end{abstract}

Keywords: Moisture content, Moringa seeds, Crude protein, Sensory.

DOI: $10.7176 / \mathrm{FSQM} / 110-04$

Publication date:September $30^{\text {th }} 2021$

\section{INTRODUCTION}

Bread is a major staple wheat based food product which has gained wide acceptance among consumers in the world especially Nigeria for many years (Badifu et al., 2005; Abulude, 2005; Olapade and Oluwole, 2013). This product is basically made from hard wheat flour, yeast, fat, sugar, salt and water. It is predominantly rich in carbohydrates and it is an appropriate vehicle for food fortification for essential macronutrients such as protein and micronutrients such as vitamins and minerals.

Wheat is the choice cereal for manufacture of bread because it contains gluten, which makes raised loaves (Olapade and Oluwole, 2013).

Bread is a high energy food, rich in carbohydrate and fat produced from wheat flour (Ameh et al, 2013). There are different varieties of bread depending on shape, weight, crust hardness, crumb cell structure, softness and colour (Bolarimwa and Raji, 2019). In order to increase the nutritional composition of bread, many studies have investigated the potentials of substituting wheat flour with other flours (Igbabul et al, 2014, Nwosu et al, 2014; Udofia et al, 2013, Onuegba et al, 2013; Abdelghafor et al, 2011; Adeleke, 2010, Sanful and Darko, Oyeyinka and Oyeyinka, 2018; Olaoye et al, 2006). Bread has been reported to have been produced from blends of wheat, maize and orange flesh sweet potato (Igbabul et al, 2014), wheat, acha and soybean (Ayo et al, 2014), wheat and un-defatted rice brain (Ameh et al, 2013), wheat and tilapia fish (Adeleke and Odedeji 2010), wheat, plantain and soybean flour (Olaoye et al,

2006) and wheat and tigernut flour (Ade Omowaye et al, 2008). Moringa oleifera also called 'miracle plant' is one of the most recently cultivated in West Africa (Olusola, 2006; Price, 2000). Moringa seed has a high protein content, on average $31.4 \%$, whereas carbohydrate, fibre and ash contents are $18.4 \%, 7.3 \%$ and $6.2 \%$ respectively. The use of Moringa seed powder for food enrichment has been reported by many studies (Nour and Ibrahim, 2016; Abioye and Aka, 2015; Arise et al, 2014, Leone et al, 2016). No one legume or cereal can provide adequate amounts of all nutrients to meet the nutritional requirements of humans (FAO,2016). However even before knowledge on protein content, protein quality, digestibility and the nutrient requirements of human became available, it was recognized that mixing legumes with cereals in the diet could improve overall nutrition (Okpala and Chinyelu, 2011).

Thus, enrichment of wheat flour with defatted Moringa seed flour for bread would improve the nutritional quality of wheat bread. The research work is aimed at accessing the effect of added defatted Moringa seed flour on the proximate, mineral and sensory properties of bread.

\section{Methods of collection of raw materials}

The ingredients used which include, wheat flour (Golden Penny brand), Moringaoleifera seeds, salt, sugar, baking yeast, were all purchased at MudaLawal market in Bauchi metropolis Bauchi sate Nigeria.

\section{Processing of defatted Moringa seed}

$1 \mathrm{~kg}$ of Moringa seeds was soaked in excess of cold water for 4 hours and then dehulled manually. The dehulled seeds were then dried at $55^{\circ} \mathrm{c}$ using hot air oven (SD 93114624, Gallenkamp, UK) for 48 hours and ground to 
coarse powder using a laboratory attrition mill. The milled seeds were then batch into subsamples of $100 \mathrm{~g}$ of five samples, and each fat extracted twice with n-hexane (1:3, w/v) as reported by Ugwuona and Suwaba (2013). The defatted coarse powder was oven dried at $60^{\circ} \mathrm{c}$ for 24 hours and then milled into fine powder and sieved through a $0.56 \mathrm{~mm}$ laboratory sieve. The product of sieve was then collected and stored in a polythene bag at room temperature $\left(29 \pm 2^{0} \mathrm{C}\right)$

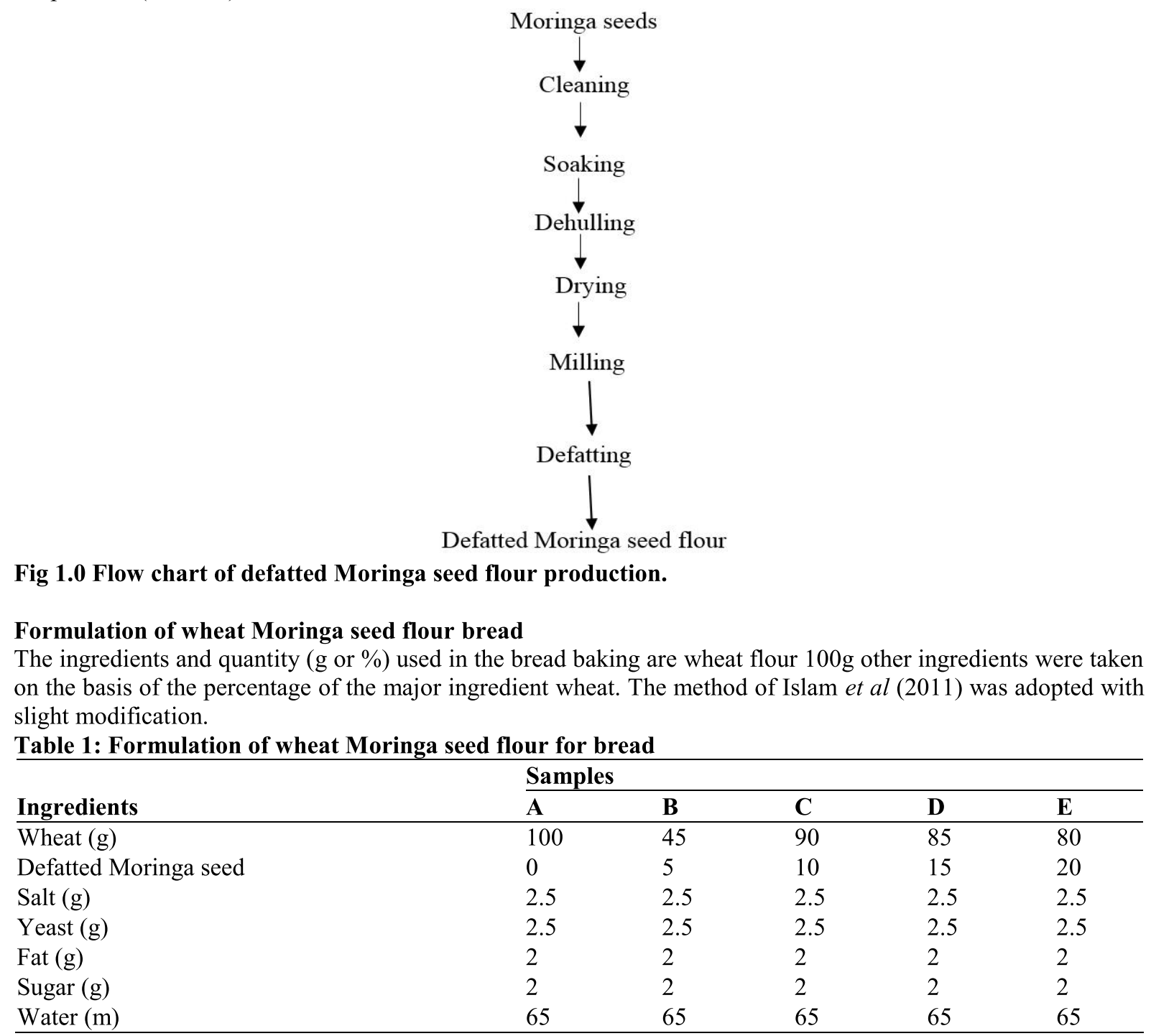

Modified Islam et al, (2011)

KEY: WHEAT: MORINGA SEED

$A=(100: 0)$

$B=(95: 5)$

$\mathrm{C}=(\mathbf{9 0 : 1 0 )}$

$\mathrm{D}=(\mathbf{8 5 : 1 5 )}$

$\mathbf{E}=(\mathbf{8 0 : 2 0 )}$

\section{Production of wheat, defatted Moringa seed composite flour bread}

The wheat, defatted Moringa seed composite flour $(200 \mathrm{~g})$ was used as the major ingredient. Other ingredients ( $2.5 \%$ fat, $2 \%$ sugar, $2.5 \%$ yeast, $2.5 \%$ salt and $65 \%$ water) were mixed with the flour to form a dough. The dough was fermented for $2 \mathrm{~h}$ at room temperature $30 \pm 2{ }^{\circ} \mathrm{C}$, remixed, cut into sizes $(100 \mathrm{~g})$, moulded, panned, proofed $\left(30 \mathrm{~min}\right.$ at room temperature $30 \pm 2^{\circ} \mathrm{C}$ ), baked (Air oven at $210^{\circ} \mathrm{C}$ for $20 \mathrm{~min}$ ), cooled, packed in low density polythene bag and stored at room temperature.

\section{Proximate composition determination}

The protein, fat, ash, crude fibre and moisture content were all determined according to the official method of the 
association of official analytical chemists (AOAC, 2005).

\section{Determination of Moisture Content}

The method described by A.O.A.C (2005) was adopted, a clean $110^{\circ} \mathrm{C}$, cooled in a desiccator and weighed (W1). Two grams of finely ground sample was dried in an oven to constant weight (W3). The percentage moisture content was calculated thus:

$$
\% \text { Moisture content }=\frac{w_{2}-w_{3}}{w_{2}-w_{1}} \quad x 100
$$

Where $\left(\mathrm{w}_{2}\right)$ is the weight of crucible plus sample before drying.

\section{Determination of Ash Content}

The A.O.A.C (2005) method was used. The porcelain crucible was dried in an oven at $100^{\circ} \mathrm{C}$ for 10 min, cooled in a desiccator and weighed $\left(\mathrm{W}_{1}\right)$. Two grams of the finely ground sample was placed into a previously weighed porcelain crucible and reweighed $\left(\mathrm{W}_{2}\right)$, it was first ignited and then transferred into a furnace which was set at $550^{\circ} \mathrm{C}$. The sample was left in the furnace for eight hours to ensure proper ashing. The crucible containing the ash was then removed; cooled in a desiccator and weight $\left(\mathrm{W}_{3}\right)$. The percentage ash content was calculated as follows:

$$
\% \text { Ash content }=\frac{w_{3}-w_{1}}{w_{2}-w_{1}} \quad x 100
$$

\section{Determination of Crude Protein}

Crude protein was determined by Kjeldahl method using Kjeltec TM model 2300, as described in Foss Analytical Manual, AB, (2003). The method involved digeston of the samples at $420^{\circ} \mathrm{C}$ for $1 \mathrm{hr}$ to liberate the organically bound nitrogen in the form of ammonium sulphate. The ammonia in the digest ammonium sulphate was then distilled off into a boric and receiver solution and then titrated with standard hydrochloric acid. A conversion factor of 6.25 was used to convert from total nitrogen to parentage crude protein.

Calculations: The percent crude protein $(\% \mathrm{CP})$ in the sample was calculated as

$\% \mathrm{CP}=\frac{(a)(b)(14)(6.25)(100)}{C}$

Where $a=$ normality of the acid

$\mathrm{b}=$ volume of standard acid used $(\mathrm{ml})$ corrected for the blank titre (i.e the sample titre - the blank titre).

$\mathrm{C}=$ sample weight $(\mathrm{g})$ and 6.25 is the conversion factor for percentage protein.

\section{Determination of Crude Lipid Content by Soxhlet Method}

A clean, dried $500 \mathrm{~cm}^{3}$ round bottom flask containing few anti-bumping granules was weighed $\left(\mathrm{W}_{1}\right)$ with 300 $\mathrm{cm}^{3}$ petroleum ether $\left(40-60^{\circ} \mathrm{C}\right)$ for extraction poured into the flask filled with soxhlet extraction unit. The extractor thimble weighing twenty grams was fixed into the Soxhlet unit. The round bottom flask and a condenser were connected to the Soxhlet extractor and cold water circulation was connected/put on. The heating mantle was switched on and the heating rate adjusted until the solvent was refluxing at a steady rate. Extraction was carried out for $6 \mathrm{~h}$. The solvent was recovered and the oil dried in an oven set at $70^{\circ} \mathrm{C}$ for $1 \mathrm{~h}$. The round bottom flask and oil was then weighed $\left(\mathrm{W}_{2}\right)$. The Lipid content was calculated thus:

$$
\% \text { Crude Lipid content }=\frac{w_{2}-w_{1}}{\text { Weight of Sample }} \times 100
$$

\section{Determination of Crude Fibre}

The sample $(2 \mathrm{~g})$ was weighed into a round bottom flask, $100 \mathrm{~cm}^{3} 0.25 \mathrm{M}$ sulphuric acid solution was added and the mixture boiled under reflux for $30 \mathrm{~min}$. The hot solution was quickly filtered under suction. The insoluble matter was washed several times with hot water until it was acid free. It was quantitatively transferred into the flask and $100 \mathrm{~cm}^{3}$ of hot $0.31 \mathrm{M}$, Sodium Hydroxide solution was added, the mixture boiled under reflux for 30 min and filtered under suction. The residue was washed with boiling water until it was base free, dried to constant weight in an oven at $100^{\circ} \mathrm{C}$, cooled in a desiccator and weighed $\left(\mathrm{C}_{1}\right)$. The weighed sample $\left(\mathrm{C}_{1}\right)$ was then incinerated in a muffle furnace at $550^{\circ} \mathrm{C}$ for $2 \mathrm{~h}$, cooled in a desiccator and reweighed $\left(\mathrm{C}_{2}\right)$.

Calculation: The loss in weight on incineration $=\mathrm{C}_{1}-\mathrm{C}_{2}$

$$
\% \text { Crude Fibre }=\frac{\mathrm{C}_{1}-\mathrm{C}_{2}}{\text { Weight of original sample }} \times 100
$$

\section{Determination of the Minerals}

The official method of the Association of Analytical Chemist (AOAC, 2005) was used for the determination of the following minerals, $\mathrm{Fe}, \mathrm{Ca}, \mathrm{Mg}, \mathrm{P}$, and $\mathrm{K}$. one (1) gram of sample was digested with nitric/perchloric/sulfuric 
acid mixture in the ratio of 9:2:1 respectively and filtered. The filtrate was made up to mark in a $5 \mathrm{ml}$ volumetric flask. The filtered solution was loaded to an Atomic Absorption Spectrophotometer (AAS) Model (AA320N Wincom).

The standard curve for each mineral was prepared from known standard of the minerals. Values of the samples were estimated against that of the standard curve.

\section{Sensory evaluation}

The bread samples were subjected to sensory evaluation using semi-trained pane lists made up largely from staff and students of the Federal Polytechnic Bauchi, Department of Food Science and Technology. The parameters evaluated upon include colour, texture, flavour, taste and general acceptability. The coded samples were served in clean white plastic plates at room temperature $\left(30 \pm 2^{\circ} \mathrm{C}\right)$ in individual booths with adequate florescent lights. Samples and check how much they liked or disliked each one and rate them as such. The panellists were given enough water to rinse their mouth between each sample test. The nine point hedonic scale (Larmond, 1997) was used for the evaluation.

\section{Statistical analysis}

The results of the proximate and sensory evaluation were subjected to analysis variance (ANOVA) using the statistical package GenState 65-bit release 17.1 (2014). Means were separated with Duncan Multiple Range Test (DMRT) at 95\% confidence level (PL0.05).

Results Table 2: Sensory Evaluation of Composite Bread Samples

\begin{tabular}{llllll}
\hline & \multicolumn{5}{c}{ Sample } \\
\cline { 2 - 6 } Attributes & $\mathbf{A}$ & $\mathbf{B}$ & $\mathbf{C}$ & $\mathbf{D}$ & $\mathbf{E}$ \\
\hline Colour & $7.15 \pm 1.39^{a}$ & $6.80 \pm 0.89^{a}$ & $6.50 \pm 1.05^{a}$ & $7.10 \pm 1.21^{a}$ & $6.75 \pm 1.16^{a}$ \\
Flavour & $7.45 \pm 0.20^{a}$ & $7.15 \pm 1.09^{a}$ & $5.55 \pm 0.94^{a}$ & $6.80 \pm 1.20^{b}$ & $7.30 \pm 1.53^{a}$ \\
Texture & $6.90 \pm 1.21^{b}$ & $6.90 \pm 1.02^{b}$ & $6.25 \pm 1.21^{b}$ & $7.05 \pm 1.59^{a}$ & $6.85 \pm 0.93^{b}$ \\
Taste & $7.50 \pm 1.00^{a}$ & $7.75 \pm 0.92^{a}$ & $5.80 \pm 1.32^{b}$ & $6.80 \pm 1.32^{b}$ & $7.60 \pm 1.45^{a}$ \\
General acceptability & $7.80 \pm 0.89^{a}$ & $7.70 \pm 0.92^{a}$ & $6.10 \pm 0.91^{b}$ & $6.95 \pm 1.32^{b}$ & $7.55 \pm 1.39^{a}$ \\
\hline
\end{tabular}

*Values with the same superscript along a row are not significantly $(\mathrm{P}<0.05)$ different for a particular attribute.

*Results are presented as mean \pm standard deviation.

KEY: WHEAT: MORINGA SEED

$$
\begin{aligned}
& A=(100: 0) \\
& B=(95: 5) \\
& C=(90: 10) \\
& D=(85: 15) \\
& E=(80: 20)
\end{aligned}
$$

Table 3: Proximate composition of composite bread

\begin{tabular}{lccccc}
\hline & \multicolumn{5}{c}{ Samples } \\
\cline { 2 - 5 } \begin{tabular}{l} 
Parameters \\
\cline { 2 - 5 } (\%
\end{tabular} & $\mathrm{A}$ & $\mathrm{B}$ & $\mathrm{C}$ & $\mathrm{D}$ \\
\hline Moisture & $12.48 \pm 0.14^{\mathrm{c}}$ & $17.99 \pm 0.14^{\mathrm{b}}$ & $19.74 \pm 0.02^{\mathrm{b}}$ & $23.73 \pm 0.16^{\mathrm{b}}$ & $23.96 \pm 0.04^{\mathrm{b}}$ \\
Ash & $1.81 \pm 0.02^{\mathrm{a}}$ & $0.56 \pm 0.02^{\mathrm{b}}$ & $0.59 \pm 0.02^{\mathrm{b}}$ & $0.23 \pm 0.14^{\mathrm{b}}$ & $0.32 \pm 0 .^{\mathrm{b}^{\mathrm{b}}}$ \\
Crude fibre & $3.60 \pm 0.21^{\mathrm{b}}$ & $3.19 \pm 0.11^{\mathrm{b}}$ & $2.57 \pm 0.17^{\mathrm{c}}$ & $5.37 \pm 0.31^{\mathrm{a}}$ & $3.00 \pm 0.07^{\mathrm{b}}$ \\
Crude fat & $7.25 \pm 0.17^{\mathrm{a}}$ & $6.86 \pm 0.08^{\mathrm{a}}$ & $4.25 \pm 0.16^{\mathrm{b}}$ & $1.81 \pm 0.02^{\mathrm{a}}$ & $4.02 \pm 0.11^{\mathrm{b}}$ \\
Crude protein & $15.66 \pm 0.07^{\mathrm{c}}$ & $15.97 \pm 0.05^{\mathrm{c}}$ & $16.25 \pm 0.14^{\mathrm{b}}$ & $17.11 \pm 0.05^{\mathrm{a}}$ & $17.16 \pm 0.35^{\mathrm{c}}$ \\
Carbohydrate & $64.61 \pm 0.24^{\mathrm{a}}$ & $59.18 \pm 0.02^{\mathrm{a}}$ & $59.76 \pm 0.02^{\mathrm{a}}$ & $55.10 \pm 0.11^{\mathrm{b}}$ & $54.86 \pm 1.11^{\mathrm{b}}$ \\
Energy (Kcal) & 386.33 & 362.30 & 342.29 & 326.19 & 324.4 \\
\hline
\end{tabular}

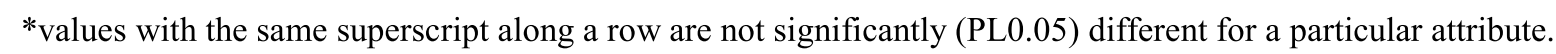

* Results on presented as mean \pm standard deviation.

KEY: WHEAT: MORINGA SEED

$$
\begin{aligned}
& A=(100: 0) \\
& B=(95: 5) \\
& C=(90: 10) \\
& D=(85: 15) \\
& E=(80: 20)
\end{aligned}
$$


Table 4: Result of Mineral content of composite bread

\begin{tabular}{llllll}
\hline & \multicolumn{5}{c}{ Sample } \\
\cline { 2 - 6 } Attributes & $\mathbf{A}$ & $\mathbf{B}$ & $\mathbf{C}$ & $\mathbf{D}$ & $\mathbf{E}$ \\
\hline Iron & $0.766 \pm 0.01^{c}$ & $2.003 \pm 0.12^{b}$ & $2.042 \pm 0.00^{b}$ & $3.726 \pm 0.02^{a}$ & $4.686 \pm 0.00^{a}$ \\
Magnesium & $2.386 \pm 0.02^{b}$ & $1.209 \pm 0.00^{b}$ & $2.591 \pm 0.02^{a}$ & $3.101 \pm 0.02^{a}$ & $3.467 \pm 0.02^{a}$ \\
Calcium & $3.287 \pm 0.06^{a}$ & $5.529 \pm 0.03^{c}$ & $7.198 \pm 0.02^{b}$ & $7.381 \pm 0.01^{b}$ & $8.794 \pm 0.15^{a}$ \\
Phosphorus & $5.732 \pm 0.11^{b}$ & $4.095 \pm 0.01^{c}$ & $4.431 \pm 0.00^{c}$ & $6.898 \pm 0.00^{a}$ & $7.703 \pm 0.10^{a}$ \\
Potassium & $1.960 \pm 0.01^{b}$ & $1.064 \pm 0.00^{b}$ & $3.450 \pm 0.01^{a}$ & $3.615 \pm 0.02^{a}$ & $4.216 \pm 0.01^{a}$ \\
\hline
\end{tabular}

*Values are means \pm standard deviation of triplicate determination. Values with same superscript along a row are not significantly $(\mathrm{P}<0.05)$ different.

KEY: WHEAT: MORINGA SEED

$$
\begin{aligned}
& A=(100: 0) \\
& B=(95: 5) \\
& C=(90: 10) \\
& D=(85: 15) \\
& E=(80: 20)
\end{aligned}
$$

\section{Discussion}

Table 2 showed the sensory evaluation of the wheat defatted Moringa seed flour composite bread. There was no significant $(\mathrm{P}<0.05)$ difference between the samples and the control in terms of colour and flavour. Samples A, B, $\mathrm{C}$ and $\mathrm{E}$ were not significantly different from each other in terms of texture and taste. In terms of general acceptability the samples scored largely high means compared with the control, with samples B and E having no significant $(\mathrm{P}<0.05)$ difference with the control sample

Table 3 showed the proximate composition of the control sample $100 \%$ wheat bread and the other substituted samples. The moisture content ranged from $12.48 \%$ to $23.96 \%$. There was a significant $(\mathrm{P}<0.05)$ increase in moisture content as substitution of wheat flour with defatted Moringa seed flour increase. However, this increase in moisture content of bread as reported by (Ayo et al., (2014) and Olapedeet al., (2014). The high moisture content is a pointer to the perishability for the products which should be consumed within 3-4 days after production. There was significant difference between the samples in terms of the crude protein which ranged from (15.66-17.16\%). There was a general increase in protein with increased defatted Moringa seed substitution. The fat content ranged from (4.02-7.25\%). There was a decrease in fat as the Moringa seed flour is increased. This is similar to what was reported by (Igbabulet al., 2014) carbohydrate ranged from 54.86 to $64.61 \%$. There was also a decrease in carbohydrate as substitution of wheat flour with Moringa seed flour is increased.

Sample A, the control sample had the highest value of $64.61 \%$ with Sample E (80:20) showing the least value of 54.86\%; similar result was reported by (Chinmaet al., 2012). Table 4 showed the result of the mineral content of the wheat-defatted Moringa seed flour bread and the control sample. The calcium content ranged from (3.287-8.794 mg/l). Calcium increase with increase with substitution. This result is similar to the work reported by Abioye and Aka (2015). It is well known that diets with high value $(\mathrm{Ca} / \mathrm{P}$ ratio are considered "good" particularly for growing children who require high intake of calcium and phosphorus for bone and teeth formation (Oluwoleet al., 2013). Also the high percentage of iron is of great importance. Iron deficiency is a serious problem worldwide, particularly for women and children (Ayo and Kajo, 2016).

\section{Conclusion}

The result obtained in this study showed there was no significant difference $(\mathrm{P}<0.05)$ in the acceptability of the control sample (A) and the other samples. Flavour increased with increased in substitution with defatted Moringa Seed flour. Crude fibre increased with increased in Moringa substitution. The protein also increased with increased Moringa substitution. Iron, Magnesium, Calcium, Phosphorus and Potassium all increased with increased in substitution of Moringa seed flour.

The increase in both protein quality and mineral constituents are positive development in boosting immunity against some pandemic like COVID-19 and HIV-AIDS.

\section{Recommendations}

i. Research should be directed towards revealing the quality of the proteins in the composited products.

ii. Further studies should focus on the physiochemical properties of the bread. iii. Based on the high nutrient profile, the product is recommended to both HIV-patients and COVID-19 patients.

iv. The formula in this research is also recommended to bakers as this will reduce their dependence on 
wheat as basic ingredient for bread.

\section{ACKNOWLEDGMENT}

The authors are thankful to the management of the Federal Polytechnic Bauchi and TETFund for providing scholarship grant, part of which facilitates this research. This indeed has given us the opportunity to contribute our quota to the nation building in terms of food security and development. Thank you so much.

\section{REFERENCES}

Abulude, F.O (2005). Distribution of selected minerals in some Nigerian white bread. Nigerian Food Journal 23:139-143.

Abdelghafor, R.F., Mustafa, A.I. and Ibrahim, A.M.H., (2011). Quality of bread from composite flour of Sorghum and hard white winter wheat. Advanced Journal of Food Science and Technology 3(1): 9-15.

Abioye, V.F., Aka, M.O., (2015). Proximate composition and sensory properties of Moringafortified maize-ogi. Journal of Nutr. And Food Science 2(5): 001-012.

Adeleke, R.O., Odedeji, J.O. (2010). Acceptability studies on bread fortified with Tilapia fish flour. Pakistan J. Nutr. 9(6), 531-534.

Ade-Omowaye, B.I.O., AKinwande, B.A., Bolarinwa, I.F., Adebiyi, A.O., (2008). Evaluation of tigernut (Cyperusesculentus) wheat composite flour and bread. Afri. J. Food. Sci. 2, 087-091.

Ameh, M.O., Gernah, D.I and Igbabul, B.D., (2013). Physico-chemical and sensory evaluation of wheat bread supplemented with stabilized undefatted rice. Bran Food and Nutrition Sciences 4(09): 43-48.

Arise, A.K., Arise, R.O., Sanusi, M.O., Esan, O.T. and Oyeyinka, S.A., (2014). Effect of Moringaoleifera flower fortification on the nutritional quality and sensory properties of weaning food. Goat. J. Food Sci. 6(2): 65 71

Ayo, J.A., Ayo, V.A., Popoola, C., Omosebi, M. and Joseph, L., (2014). Production and evaluation of malted soybean-acha composite flour bread and biscuit. African Journal of Food Science and Technology 5(1): 21 -28 .

Badifu, I.O., Chima, C. E; Ajayi, Y.I and Ogoro, A.F (2005). Influence of Mango Mesocarp Flour Supplementation on Micronutrient, Physical and Organoleptic Qualities of Wheat bread. Nigerian Food Journal 23:59-68.

Bolarinwa, I.F. and Raji, A.O., (2019). Nutritive and acceptability of bread fortified with Moringa seed powder. Journal of the Saudi Society of Agricultural Sciences 18(2): 195-200.

Chinma, C.E., Gbadamosi, K.B., Ogunsina, B.S., Oloyede, O.O. and Salami, S.O., (2014). Effect of addition of germinated Moringa seed flour on the quality attributes of whet based cake. Journal of Food Proc. And Pres. 38:1737-1742.

Igbabul, B.D., Num, G., AMove, J., (2014). Quality evaluation of composite bread produced from wheat, maize and orange fleshed sweet potato flour. Am. Journal of Food Science Technology 2(4): 109-115.

Islam, M. Z., Taneya, M. L. J., Shams-Ud-Din, M., Syduzzaman, M., \&Hoque, M. (2011). Physicochemical and functional properties of brown rice (Oryzasativa) and wheat

(Triticumaestivum) flour and quality of composite biscuit made thereof. Scientific Journal of Krishi Foundation, 10(2), 20-28. http://doi.org/10.3329/agric.v10i2.13135

Leone, A., Spada, A., Battezzati, A., Schiraldi, A., Aristil, J. and Bertoli, S., (2016). Moringaoleifera seeds and oil. Characteristics and uses for human health. Int. J. Mol. Sci. 17:2141

Nwosu, J.N., Owuamanam, C.I., Omeire, G.C., Eke, C.C., (2014). Quality parameters of bread produced from substitution of wheat flour with cassava flour using Soybean as an improver. American Journal of Research Communication 2(3): 99-118.

Okpala, L.C. and Chinyelu, V.C., (2011). Physico-chemical, nutritional and organokptic evaluation of cookies from Pigeon peas (Cajanacajan) and Cocoyam (Xanthosona sp.) flour blends. Afr. J. Agr. Nutr. And Dev. (AFJAND) 11(6). 5432-5433.

Olaoye, O.A., Onilude, A.A., Idowu, O.A., (2006). Quality characteristics of bread produced from composite powders of wheat, plantain and soybeans. Afr. J. Biotechnol. 5(11): 1102-1106.

Onuegbu, N.C., Inediohanma, N.C., Odunze, O.F., Ojukwu, M., (2013). Efficiency of wheat: maize composite flour as affected by baking method in bread and cake production. Sky K. Food Sci. 2(8), 005-013.

Olapade, A.A and Oluwole, O.B (2013). Bread making potential of composite flour wheat - Acha (Digitaria exilis staph) Enriched with cowpea (Vigna unguiculata L. Walp) flour. NIFOJ 33(1):6-12.

Oyeyinka, A.T., and Oyeyinka, S.A., (2018). MoringaOleifera as a food fortificant: recent trends and prospects. J. Saudi Society of Agric. Sci. 17(2): 127-136. 
Price, L.L., (2000). The Moringa tree (www.echonet.org (accessed on 27/6/2021)

Sinful, R.E., Darko, S., (2010). Utilization of Soybean flour in the production of bread. Pakistan J. Nutr. 9(8): 815-818.

Udofia, P.G., Udoudo, P.J. and Eyen, N.O., (2013). Sensory evaluation of wheat-cassava-soybean composite flour (WCS) bread by the mixture experiment design. African Journal of Food Science 7(10): 368-374 